\title{
E-Racing Racial Profiling
}

\author{
DAVID M. TANOVICH*
}

Despite widespread denials, racial profiling is a serious problem in many Canadian jurisdictions. The time has come to stop the debate and to focus instead on remedial action that directly addresses the problem. The author begins with an analysis of the dynamics of racial profiling and notes the challenges it poses to institutional measures aimed at changing police culture, such as anti-racism training and hiring practices. Since the breeding ground for racial profiling is the day-to-day crime detection policing that occurs through vehicle and pedestrian stops, one significant step that can be taken is to compel the police to record and publish stop data. This remedial approach has been put into practice in England and in much of the U.S. The author further proposes a revamping of the public complaints system. An objective and independent public complaints process is lacking and formal measures must be taken in this area to improve police accountability. The author also suggests that anti-racial profiling legislation is needed. Perhaps most importantly, law reform is required. To this end, the author details several specific recommendations to stimulate law reform in Canada.
Malgré le fait que ce soit généralement nié, l'établissement de profils raciaux représente un sérieux problème dans de nombreuses juridictions canadiennes. Il est temps d'arrêter le débat et de se pencher plutot sur des mesures correctives abordant directement le problème. L 'auteur commence par une analyse de la dynamique de l'établissement de profils raciaux et indique les difficultés que cela représente pour les mesures institutionnelles qui visent à changer la culture de la police comme les pratiques antiracistes de formation et d'embauche. Comme le vivier de l'établissement de profils raciaux est la détection de crimes au jour le jour que la police effectue au moyen d'arrêts de véhicules et de piétons, le fait de demander à la police d'enregistrer et de publier les données sur ces arrêts pourrait s'avérer un pas important. Cette démarche corrective a été mise en pratique en Angleterre et dans une grande partie des États-Unis. L'auteur suggère de réorganiser le système de plaintes du public. Il manque un processus objectif et indépendant de plaintes du public et il faut prendre des mesures officielles dans ce domaine pour améliorer la responsabilité de la police. L'auteur indique aussi qu'une législation interdisant l'établissement de profils raciaux s'impose. Il est peut-être plus important de réformer la loi. À cette fin, l'auteur donne les détails de plusieurs recommandations spécifiques visant à stimuler la réforme de la loi au Canada.

\section{TABLE OF CONTENTS}

I. INTRODUCTION . . . . . . . . . . . . . . . . . . . . . . . 906

II. UNDERSTANDING THE DYNAMICS OF

Racial Profiling ...........................911

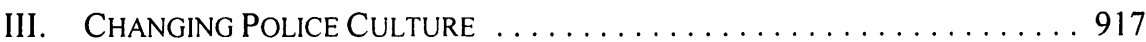

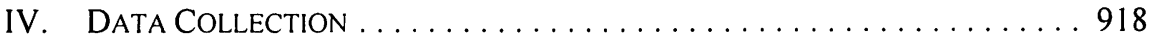

A. ENGLAND ............................. 921

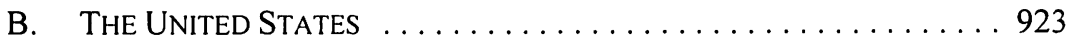

C. CANADA ................................. 924

V. REVAMPING THE Public COMPLAINTS SYSTEM $\ldots \ldots \ldots \ldots \ldots \ldots 925$

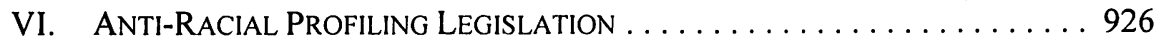

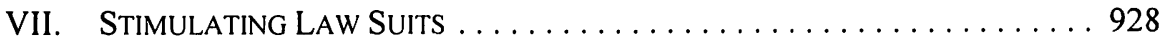

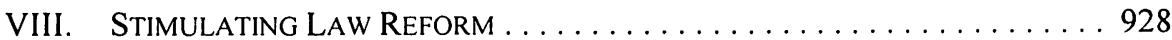

Assistant Professor, Faculty of Law, University of Windsor. An earlier version of this article was presented to the Ontario Civilian Commission on Police Services (9 June 2003) on behalf of the African Canadian Community Coalition, a coalition of more than 30 community groups in Toronto. 
A. RECOMMENDATION \#1: THE SUPREME COURT

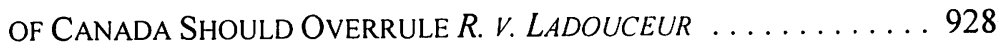

B. RECOMMENDATION \#2: COURTS MUST FACTOR IN

THE RELEVANT SOCIAL CONTEXT OF RACIAL

PROFILING WHEN DETERMINING THE CHARTER

STANDARDS TO GUIDE POLICE POWERS OF

STOP AND SEARCH . . . . . . . . . . . . . . . . . . . . . 929

C. RECOMMENDATION \#3: THE CROWN SHOULD BEAR

THE ONUS UNDER SECTION 9 OF ESTABLISHING

on a Balance of Probabilities that a VeHICLE

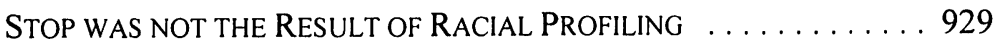

D. RECOMMENDATION \#4: All STREET LEVEL CRIMINAL

INVESTIGATIONS SHOULD BE DEEMED A DETENTION

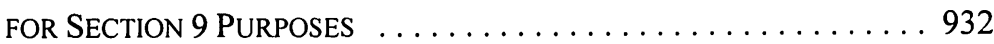

IX. COnCLUSION ................................ 933

\section{INTRODUCTION}

Largely as a result of the Toronto Star's expose on race and crime in October of 2002, the sensitive issue of racial profiling of the African-Canadian community in Toronto is finally getting the attention that it requires. ' The problem, however, is that most of that attention has been on whether or not the practice exists. After the Toronto Star report was published, the Toronto public heard almost nothing but constant and vehement denials by the police union, the police brass, and the mayor. ${ }^{2}$ In addition, the police went on the offensive. Chief of Police Julian Fantino hired Professor Ed Harvey from the University of Toronto and well-known

1 The initial lead articles in this series included: Jim Rankin et al., "Singled Out" Toronto Star (19 October 2002) A1; "Police target black drivers" Toronto Star (20 October 2002) A1; "Black arrest rates highest" Toronto Star (26 October 2002) A2; and "Life and death on mean streets" Toronto Star (27 October 2002) A2. The Toronto Star explained the purpose of the series as follows: "[a]t various times, concerns about relations between the police and minorities, questions about arrests and charges, have been raised by the city's minority communities. We believe it is the duty of a newspaper and its journalists to seek out the truth, to focus attention on practices and issues that need to be discussed and addressed.... Our stories detail troubling facts surrounding minorities and police, and indicate it is time for the issue to be dealt with calmly and rationally"( Mary Deanne Shears, "Our Duty: Examine all issues" Toronto Star (19 October 2002) A2). In addition to relying on previous studies on systemic racism and policing, the Star conducted its own analysis based on data obtained from the police database known as CIPS - the Criminal Information Processing System. The data covered the period from 1996 to 2002 and involved more than 480,000 arrest'ticketing incidents and nearly 800,000 criminal and other charges (see "The story behind the numbers" Toronto Star (19 October 2002) A12). The Toronto Police Association: "[n]o racial profiling has ever been conducted by the Toronto Police Services" (Catherine Porter, "Police union urges Star boycott" Toronto Star (22 October 2002) A6); Chief Julian Fantino: "we do not do racial profiling" ("Fantino: "We do not do racial profiling"" Toronto Star (19 October, 2002) A2); and Colin Perkel, “Ontario Chiefs back Fantino's profiling denial" Toronto Star (29 October 2002), online: Toronto Star <www.thestar.com>); Police Services Board Chair Norman Gardner: "Toronto police profile by crime, not by race" (Philip Mascoll, "No racial profiling by police: Gardner" Toronto Star (18 November 2002) B4); Mayor Mel Lastman: "police only arrest the 'bad guys'. I don't believe that Toronto police engage in racial profiling in any way, shape or form" ("Analysis raises board hackles" Toronto Star (20 October 2002) A9). 
defence lawyer Alan D. Gold to review the Toronto Star's interpretation of the police data. ${ }^{3}$ Then, in a well-orchestrated manoeuver, Harvey and Gold attended a Toronto Police Services Board meeting that had been advertised as an opportunity for the Black community to express their profiling concerns, and proclaimed that the newspaper's conclusions were "bogus" and based on "junk science." In addition, the Toronto Police Service Association launched an unprecedented 2.7 billion dollar lawsuit against the Toronto Star. The basis for the lawsuit was, as police union lawyer Tim Danson put it, "[a]ccusing the members of the Toronto Police Service of racism."

Denial has not been the exclusive province of the Toronto police. When Ottawa Deputy Chief Larry Hill admitted at a conference on multiculturalism and policing that racial profiling exists within the Ottawa force, the president of the Ottawa Police Association Sergeant Byron Smith stated, "[w]e assert that we don't take part in racial profiling" and "so we kind of distanced ourselves from what (Hill) had to say about it." Similarly, the president of the Ontario Association of Chiefs of Police has stated that "it's certainly not something that we're that concerned about because we don't believe that it exists" and "it's our position that (racial profiling) does not exist. We're not doing that."7

Unfortunately, the targeting of racial minorities for criminal or security-related investigation, solely or in part on the basis of their skin colour, is a real and serious problem in many jurisdictions. In England, for example, the Home Secretary reported in its 2003 annual report on race relations that "the 2001/02 figures showed that black people were eight times more likely to be stopped and searched than white people. This was a rise from five

$3 \quad$ Edward B. Harvey, "An Independent Review of the Toronto Star Analysis of Criminal Information Processing System (CIPS) Data Provided by the Toronto Police Services," online: Toronto Police Service <www.torontopolice.on.ca/publications/files/reports/harveyreport.pdf>. The integrity of Harvey's review is challenged by Scot Wortley \& Julian Tanner, "Data, Denials and Confusion: The Racial Profiling Debate in Toronto" (2003) 45 Can. J. Crim. 367. See also Harold Levy, "Police rebuttal called flawed" Toronto Star (10 June 2003) Al.

$4 \quad$ Paul Moloney, "Police attack Star's race articles: Police chief's race response gets crowd's full attention — Lawyer calls articles "junk science"” Toronto Star (21 February 2003) Al ; "Text from Toronto Police Service website" Toronto Star (21 February 2003) Al; and Catherine Porter, "Act, don't fight, police told" Toronto Star (21 February 2003) B1. See also Alan D. Gold, "Media Hype, Racial Profiling and Good Science" (2003) 45 Can. J. Crim. 391 at 391-92; and Alan D. Gold, "Profiling Debate," Alan D. Gold Collection of Criminal Law Articles, ADGN/2002-448 (QL). In the United States, the biggest proponent of the idea that racial profiling is a myth is Heather MacDonald of the Manhattan Institute (see Heather MacDonald, Are Cops Racist? (Chicago: Ivan R. Dee, 2003) at 9-34).

$5 \quad$ See Peter Small, "Police union sues Star over race-crime series" Toronto Star (18 January 2003 ) A6. The lawsuit was eventually dismissed on a pre-trial motion. Justice Cullity was satisfied that the statement of claim disclosed no cause of action:

The whole thrust of the articles is that the evidence suggests that racial profiling occurs and that steps must be taken to identify the causes and remove them. In my judgment, the allegedly defamatory comments and innuendos in the articles cannot reasonably be understood as intended to apply to every officer in the TPS. This conclusion destroys the foundation of the plaintiff's cause of action as their claim to have been libelled ... depends upon a finding to the contrary. (Gauthier v. Toronto Star Daily Newspapers Ltd. (2003), 228 D.L.R. (4th) 748 (Ont. S.C.J.) at para. 28.

" See Chris Sorensen, "Ottawa police, deputy chief at odds over racial profiling" Toronto Star (2 March 2003) Al.

7 Perkel, supra note 2. 
times more likely in 1999/2000 and seven times more likely in 2000/01."8 In Ontario, the Ontario Human Rights Commission (OHRC) made the following observations in its 2003 report, Paying The Price: The Human Cost Of Racial Profiling:

It is the Commission's view that previous inquiries have considered [the existence of racial profiling] and have found that it does occur.

Moreover, ... racial profiling is a form of racial stereotyping. As racial stereotyping and discrimination exists in society, it also exists in institutions such as law enforcement agencies....

Racial profiling has long been acknowledged to exist in other western nations, most notably the United States and Britain.

... [There are] 15 reports since the 1970 s dealing with police/minority relations in Canada... In 1992, the Ontario government also established the Commission on Systemic Racism in the Ontario Criminal Justice System.... The review confirmed the perception of racialized groups that they are not treated equally by criminal justice institutions...

In addition to the various task forces, social scientists, criminologists and other academics have studied racial profiling ... these studies have consistently showed that law enforcement agents profiled racial minorities. ${ }^{9}$

Not surprisingly, in R. v. Brown, ${ }^{10}$ the Ontario Court of Appeal took judicial notice of the existence of racial profiling. For the Court, Morden J. held:

[i]n the opening part of his submission before this court, counsel for the appellant [the Crown] said that he did not challenge the fact that the phenomenon of racial profiling by the police existed. This was a responsible position to take because, as counsel said, this conclusion is supported by significant social science research. I quote from the Report of The Commission on Systemic Racism in the Ontario Criminal Justice System (Toronto: Queen's Printer for Ontario, 1995) (Co-chairs: M. Gittens and D. Cole) at 358:

The Commission's findings suggest that racialized characteristics, especially those of black people, in combination with other factors, provoke police suspicion, at least in Metro Toronto. Other factors that may attract police attention include sex (male), youth, make and condition of car (if any), location, dress, and perceived lifestyle. Black persons perceived to have many of

U.K., Home Office, Stephen Lawrence Inquiry: Home Secretary's Action Plan Fourth Annual Report on Progress (London: Home Office Communication Directorate, 2003), online: Home Office <www. homeoffice.gov.uk/docs/slawr_annrep4.pdf $>$. See also U.K., Home Department, The Stephen Lawrence Inquiry: Report of an Inquiry by Sir William Macpherson of Cluny, Cmnd 4262-1 (London: Her Majesty's Stationary Office, 1999) at c. 45.8-45.10, online: The Stationary Office Official Documents $<$ www.archive.official-documents.co.uk/document/cm42/4262/sli-45.htm> [Macpherson Report]; Laurence Lustgarten, "The Future of Stop and Search" [2002] Crim. L. Rev. 603; and U.K. Home Office Research and Statistics Directorate, Ethnicity and Contacts with the Police: Latest findings from the British Crime Survey (Research Findings No. 59) by Tom Bucke (London: Her Majesty's Stationary Office, 1997), online: Home Office <www.homeoffice.gov.uk/rds/pdfs/r59.pdf $>$. In the United States, see David A. Harris, Profiles In Injustice: Why Racial Profiling Cannot Work (New York: The New Press, 2002) at c. 2-4. (Inquiry Report) (2003) at 9-10, online: <www.ohrc.on.ca/english/consultations/racial-profilingreport.pdf> [OHRC Report]. (2003), 64 O.R. (3d) 161, 9 C.R. (6th) 240 [Brown cited to C.R.]. 
these attributes are at high risk of being stopped on foot or in cars. This explanation is consistent with our findings that, overall, black people are more likely than others to experience the unwelcome intrusion of being stopped by the police. ${ }^{11}$

Strong words and actions and yet, the denials continued. In the days following the release of the OHRC Report, senior police officials resumed the denial game. In a press conference, Chief Fantino angrily stated that the report was "totally divorced from the reality of today" 12 and also that "I don't believe our police are so corrupt, so dishonest, so racist, that we need to have body packs on them, cameras on their back and watchdogs at everything they do."13 Meanwhile, the President of the Ontario Association of Chiefs of Police described the report as "predictably disappointing and unfair." 14

The time has come to stop the debate. ${ }^{15}$ As the OHRC Report forcefully states, "the time has come to act" and to focus on remedial action. ${ }^{16}$ All of the relevant actors must work together to devise strategies to address this insidious problem whose collateral effects are substantial. ${ }^{17}$ Using the experience of the Black community in Toronto as my context, the

11 Ibid. at 246. In his annotation to the case, Professor Stuart highlighted that "this panel of justices relies on the Report of The Commission on Systemic Racism in the Ontario Criminal Justice System ... for establishing the existence of racial profiling in Ontario" ("R. v. Brown: Annotation" (2003) 9 C.R. (6th) 240 at 243). In its report, the OHRC also referred to the Brown case (ibid.) as an example of judicial recognition of racial profiling (OHRC Report, supra note 9 at 10$)$. Darren Yourk, "Toronto police chief slams racial profiling report" The Globe and Mail (9 December 2003), online: The Globe and Mail <www.theglobeandmail.com>; John Barber, "Fantino reaction to race report has no substance" The Globe and Mail (10 December 2003) A21.

13. Richard Mackie, "Fantino blasts proposed police cameras" The Globe and Mail (11 December 2003) A18. This quote was Chief Fantino's response to the OHRC recommendation to use video cameras in police vehicles to identify and deter profiling.

14 Sonia Verma \& Cal Millar, "Fantino angered by report" Toronto Star (10 December 2003) A10.

is There does appear to be a breath of fresh air with the new Liberal government in Ontario. Early accounts suggest that the McGuinty government is prepared to acknowledge and address the problem (see Richard Brennan \& Robert Benzie, "Province to Fantino: Deal with profiling" Toronto Star (11 December 2003) Al and "McGuinty defends police-car cameras" Toronto Star (10 December 2003) $\mathrm{Al}$; and Richard Brennan, "Liberals vow guidelines against racial profiling" Toronto Star (9 November 2003) A4).

16 OHRC Report, supra note 9 at 73 . This sentiment has also been repeatedly expressed by most of the leaders in the Black community in Toronto (see Harold Levy, "Face racial profiling, police agency urged" Toronto Star (16.June 2003) A19; Catherine Porter, "Act, don't fight, police told" Toronto Star (21 February 2003) B1; Catherine Porter, "Action urged on pace profiling" Toronto Star (19 January 2003) A11; and "Stop Talking About Racism, Do Something: Toronto Coalition" CBC News (31 October 2002), online: $C B C<w w w . c b c . c a /$ storyview/CBC/2002/10/31/to_police021031>).

17 Some of the costs of profiling are documented in the OHRC Report, supra note 9 at 17-66. They include alienation and a diminished sense of citizenship, distrust of our institutions, loss of dignity, stressrelated disorders, over-representation in the criminal justice system, stigmatization, widespread harassment, and forced changes in behaviour. See also David M. Tanovich, "Using The Charter To Stop Racial Profiling: The Development of an Equality-Based Conception of Arbitrary Detention" (2002), 40 Osgoode Hall L.J. 145 at 161-65 [Tanovich, "Using the Charter"]. Often overlooked in the discussion of the collateral effects are the deadly consequences of profiling. Historically, the stereotypes that fuel profiling have likely played some role in the approximately. 30 Black individuals who have been killed or injured in police shootings in Ontario (25) and Quebec (five) since 1978. Presently, we are witnessing a deadly consequence of racial profiling manifested in the series of shootings in the Black community in Toronto. If you over-police a group that is already marginalized and discriminated against and then imprison its youth in large numbers for relatively minor offences, it is only logical to assume that those coming out of prison may feel that they have no choice but to turn to greater levels 
purpose of this article is to identify some of the remedial steps that can be undertaken to address racial profiling. ${ }^{18}$ These steps include:

a public awareness campaign designed to ensure that the public and the police understand the racial profiling phenomenon including what it is, why it exists, and why it is not an efficient or reasonable police practice;

the promulgation of an official written police policy prohibiting the use of racial profiling;

improving efforts at changing police culture and making the hiring and promoting of more visible minority officers a priority;

compelling the police to record the circumstances surrounding all stops including the race and ethnic background, age and gender of the person stopped, the reasons, and the results of the stop;

of criminality in order to gain access to scarce resources. Moreover, research into profiling suggests that the sense of disrespect for the rule of law and other conventions that profiling engenders can lead to further offending. Finally, no one should be surprised that if members of a community are treated and repeatedly portrayed as violent criminals, some individuals will start acting that way.

And we are now seeing the deadly consequences of the over-policing of the Aboriginal community in Western Canada. On 16 January 2004, Police Complaint Commissioner of British Columbia Dirk Ryneveld urged a public inquiry into the death of Frank Paul. Paul died of hypothermia in 1998 after being abandoned by two police officers in an alley in Vancouver's eastside. He joins six other Aboriginal men in Saskatchewan who were also found frozen to death. These men include Neil Stonechild, Rodney Niastus, Lawrence Wegner, Russell Charles, Lloyd Dustyhorn, and Darcy Ironchild. In many of these cases, there is evidence that the men had earlier been in police custody. Two other Aboriginal men, Darrell Night and Garret Berthelette were able to escape death after being abandoned by the police in Saskatchewan and Manitoba. These cases do not appear to be aberrations. So common is this practice of targeting intoxicated Aboriginals and exiling them in the middle of winter in Saskatchewan, it is known as a "starlight tour." In its 2001 Report, Amnesty International expressed grave concerns about this practice; in the summer of 2003, Saskatoon Chief of Police Russell Sabo conceded that an officer was disciplined in 1976 for abandoning an Aboriginal woman and that it was "quite conceivable that there were other[s]." In British Columbia, the practice is known as "breaching." This issue of profiling and the practice of "starlighting" is likely to be addressed by the Saskatchewan inquiry looking into Neil Stonechild's death (see Gabriella Pedicelli, When Police Kill: Police Use of Force in Montreal and Toronto (Montreal: Véhicule Press, 1998) at 65; Rod Mickleburgh, "Inquiry urged in case of Native left in alley" The Globe and Mail (21 January 2004) A8; Office of the Police Complaint Commissioner, Frank Joseph Paul Reasons for Decisions (16 January 2004), online: Office of the Police Complaint Commissioner <www.opcc.bc.ca/Public\%20Hearing\%20_\%20PCC\% 20Reasons/2004/Paul\%20reasons.html>; Saskatchewan, Commission of Inquiry Into Matters Relating to the Death of Neil Stonechild, online: Stonechild Inquiry <www.stonechildinquiry.ca>; "Timeline" CBC News (9 June 2003), online: $\mathrm{CBC}<$ www.cbc.ca/news/indepth/firstnations/stonechild. html>; "Starlight Tours" $C B C$ News (n.d.), online: $C B C<w w w . c b c . c a / n e w s / i n d e p t h / f i r s t n a t i o n s /$ starlighttours.html>; and R. v. Munson, [2004] 2 W.W.R. 107, (2003), 232 Sask. R. 44 (C.A.)).

While the focus of racial profiling has been on the over-surveillance of the African-Canadian community on the streets of Toronto, the practice occurs in other parts of Ontario and Canada (e.g. Montreal and Halifax), to other groups (e.g. Aboriginals and Arabs), and in other contexts (e.g. airports and shopping malls). See e.g. Troy v. Kemmir Enterprises (c.o.b. Petro Canada), [2003] B.C.J. No. 2933 (QL), 2003 BCSC 1947; Anne Sutherland, "Black youth group proposes ideas to counter racial profiling" Montreal Gazette (8 March 2004) A7; OHRC Report, supra note 9 at 6-8 and 54-66; Manitoba, Public Inquiry Into The Administration of Justice and Aboriginal People, vol. 2 (Winnipeg: Queen's Printer, 1991); the discussion of "starlight tours" at supra note 17; and Johnson v. Halifax (Regional Municipality) Police Service, [2003] N.S.H.R.B.I.D. No. 2 (QL) [Johnson]. See also Reem Bahdi, "No Exit: Racial Profiling And Canada's War Against Terrorism" (2003) 41 Osgoode Hall L.J. 293. Most, if not all, of what is recommended in this article applies to addressing the profiling of these other groups. 
- making the public complaints process more objective, fair, and accessible;

- $\quad$ enacting anti-racial profiling legislation; and

- stimulating law suits and law reform.

\section{Understanding the Dynamics of Racial Profiling}

Anti-Black racism is an emotive word that conjures up images of slavery, the Jim Crow laws, the Klu Klux Klan, and hate crimes. This imagery is not confined to the American experience. Contrary to popular mythology and our desire to differentiate ourselves from our southern neighbours, these images of brutality and dominance are part of our own history. ${ }^{19}$ For example, Canada has a two hundred year history of slavery that was not formally abolished until $1834 .{ }^{20}$ It also has a twentieth century history of de-facto racial segregation ${ }^{21}$ and of substantial Klu Klux Klan presence and activities. ${ }^{22}$

Associating racial profiling with this imagery no doubt explains, in part, the hostile and defiant manner in which the police, some public officials, and even the public have responded to claims of its existence. Equating racial profiling with overt racism has unfortunately resulted in a misunderstanding of the phenomenon and has stifled rational debate and reform. The targeting of certain racial groups for criminal or security-related investigation is not, generally speaking, a manifestation of overt racism. Most of the officers who use race as a part of a profile are not doing so because of a deep-seated hatred of members of a particular group. ${ }^{23}$ Nor is there likely to be a "smoking gun" buried in some police instruction manual that teaches or encourages police officers to target certain racial

1.) See Constance Backhouse, Colour-Coded: A Legal History of Racism in Canada, 1900-1950 (Toronto: University of Toronto Press, 1999) [Backhouse, Colour-Coded] for a discussion of Canada's history of racism in relation to Aboriginals, Asian-Canadians, and African-Canadians.

See Carol A. Aylward, Canadian Critical Race Theory: Racism and the Law (Halifax: Fernwood Publishing, 1999) at 39-49; Barry Cahill, "Slavery and the Judges of Loyalist Nova Scotia" (1994) 43 U.N.B.L.J. 73; H.T. Holman, ed., "Slaves And Servants On Prince Edward Island: The Case Of Jupiter Wise" (1982) 12 Acadiensis 100; Errol Mendes, ed., "Racial Discrimination": Law and Practice (Toronto: Carswell, 1995); James W. St. G. Walker, "Race, "Rights and the Law in the Supreme Court of Canada (Ontario: The Osgoode Society for Canadian Legal History and Wilfrid Laurier University Press, 1997); and Robin W. Winks, The Blacks In Canada: A History (Montreal: McGill-Queen's University Press, 1971).

21 See Constance Backhouse, "Racial Segregation in Canadian Legal History: Viola Desmond's Challenge, Nova Scotia, 1946" (1994) 17 Dalhousie L.J. 299; and Backhouse, “'Bitterly Disappointed' at the Spread of "Colour-Bar Tactics"' in Colour-Coded, supra note 19 at 250-52. There is even a history of judicial recognition of segregation in cases like Christie v. York, [1940] S.C.R. 139 [Christie] and Rogers v. Clarence Hotel, [1940] 3 D.L.R. 583, 2 W.W.R. 545 (B.C.C.A.), where the Supreme Court of Canada and the British Columbia Court of Appeal respectively concluded that businesses had the right to refuse to serve persons of colour. See also Loew's Montreal Theatres Ltd. $v$. Reynolds (1919), Q.R. 30 K.B. 459, cited in Christie, ibid.; and Franklin v. Evans (1924), 55 O.L.R. 349, O.J. No. 33 (QL) (S.C. (H.C. Div.)).

22 See Backhouse, Colour-Coded, supra note 19 at 181-93. Backhouse points out, for example, that by 1925 there were estimates of 8,000 Klan members in Toronto and 25,000 members in Saskatchewan and established offices, rallies, and cross burnings across British Columbia, Saskatchewan, Alberta, Ontario, Quebec, New Brunswick, and Nova Scotia.

23. Those officers who use profiling as a manifestation of overt racism are the individuals that most people think of when the term "bad apples" is used in this context. See John Deverell, "Chief defends his force: Police Act powers enough to curb any "bad apples"' Toronto Star (4 June 2003) B5; and Ontario, Report of the Commission on Systemic Racism in the Ontario Criminal Justice System, vol. 1 (Toronto: Queen's Printer for Ontario, 1995) at 357 [Ontario Systemic Racism Report]. 
minorities. As the authors of the Report of the Commission on Systemic Racism in the Ontario Criminal Justice System have pointed out:

A common feature of [previous] inquiries [into racism] is an emphasis on "systemic" or "institutional" racism as opposed to individual or overt racism. They have generally assumed that the vast majority of professionals in the criminal justice system under examination do not consciously intend to treat racial minority people worse than white people. Nevertheless they have recognized that even a criminal justice staffed with wellintentioned professionals may operate in subtle and unfair ways that have adverse impacts on racial minority and indigenous peoples. These inquiries have therefore attempted to identify discriminatory practices with the object of eliminating them.

This Report takes the same approach. The Commission assumed that persons with explicitly hostile attitudes towards racial minority people would constitute no more than a tiny minority of professionals within the criminal justice system. ${ }^{24}$

That said, our history of overt racism does explain to some extent the failure of many and, in particular, of the police to critically evaluate the assumptions and stereotypes discussed below that have fueled the practice of racial profiling.

Racial profiling is yet another manifestation of systemic racism. It is the unintentional process of "social production of racial inequality in decisions about people and the treatment they receive." ${ }^{25}$ How does this occur and how can it be said to be unintentional when a police officer is conscious of the fact that he or she is stopping a person of colour? In order to answer these questions, it is necessary to step back and look at the complex process of how we evaluate behaviour. The social science literature suggests that people often make decisions about strangers based on general beliefs or stereotypes associated with the characteristics of the stranger's group (that is, his or her race, gender, or ethnicity). As one commentator has observed:

Social scientists and cognitive psychologists have studied the manner in which people make sense of themselves and others. In encountering the complexities of our daily lives, we attempt to reduce the social world around us into categories to create a more manageable structure. This process of categorization enables us to organize and make decisions about information with less time and effort than we would require to confront behaviour and events anew. As the human mind seeks to understand conduct, it looks to salient cues, such as race and ethnicity, and then draws on culturally embedded understandings to evaluate behaviour. ${ }^{26}$

Ibid at 39 . Systemic racism is by no means confined to the police. We now know that it is unfortunately present in every social institution in Canadian society. See the discussion in Anti-Black Racism in Canada: A Report on the Canadian Government's Compliance with the International Convention on the Elimination of All Forms of Racial Discrimination (Toronto: African Canadian Legal Clinic, 2002), on file with the author; Ontario Systemic Racism Report, supra note 23 at Chapter 3; and Multiculturalism and Citizenship Canada, Eliminating Racial Discrimination in Canada, (Ottawa: Supply \& Services Canada, 1989) at 3-7. See also the discussion in relation to Aboriginal peoples in R. v. Williams, [1998] 1 S.C.R. 1128 at paras. 20-31, 15 C.R. 227 [Williams cited to S.C.R.]; and $R$. v. Gladue, [1999] 1 S.C.R. 688 at paras. 58-74, 133 C.C.C. (3d) 385. N.Y.U. L. Rev. 956 at 983-86. See also the discussion in Alan W. Mewett, "Secondary Facts, Prejudice and Stereotyping" (1999) 42 Crim. L. Q. 319; and Marilyn MacCrimmon, "Developments in the Law of Evidence: The 1995-96 Term: Regulating Fact Determination and Commonsense Reasoning" (1997) 8 Sup. Ct. L. Rev. (2d) 367 at 368-74. 
Using categorizations or schemas to guide evaluations of behaviour is almost inevitable. As the OHRC observed in its report, "[p]ractical experience and psychology both confirm that anyone can stereotype, even people who are well meaning and not overtly biased." ${ }^{27}$ This is particularly so in cases where the generalized beliefs are reinforced through previous experiences, the prevailing pop-culture, and the media. The literature also suggests that the faster a decision needs to be made, the more likely it is that the decision-maker will resort to these group stereotypes. It is not a leap of logic to conclude that this is even more so where the decision is perceived to involve officer safety or potential criminal or terrorist activity. ${ }^{28}$

In the context of race, this categorization process is known as racialization. It is described as follows:

Racialization is the process by which societies construct races as real, different and unequal in ways that matter to economic, political and social life. It involves -
selecting some human characteristics as meaningful signs of racial difference;
sorting people into races on the basis of variations in these characteristics;
attributing personality traits, behaviours and social characteristics to people classified as members
of particular races; and
acting as if race indicates socially significant differences among people. ${ }^{29}$

How does racialization operate in the context of policing? It is a common police practice to use historical experiences as a guide to future policing, especially proactive policing, which involves identifying a potential suspect. This is precisely why so many different profiles have been created over the years by the police - the hijacker profile, the smuggler profile, the serial-killer profile, and the terrorist profile. In the context of drugs, a drug-courier profile is widely used in the United States, as most states have incorporated a DEA training program known as "Operation Pipeline" that teaches officers to look for "indicators" of drug trafficking during vehicle stops. ${ }^{30}$ In Canada, a drug-courier profile based on "Operation Pipeline" is now used in a number of provinces. ${ }^{31}$

While "Operation Pipeline" involves a more formalized use of profiling, a form of informal profiling can arise from personal experiences. One of the most common police experiences is the process of arrest, booking, and appearing in court to testify. From these

$27 \quad$ OHRC Report, supra note 9 at 6.

28. Thompson, supra note 26 at 986-87.

29 Ontario Systemic Racism Report, supra note 23 at 40 [emphasis in original]

30 "Operation Pipeline" has been linked to racial profiling (see Harris, supra note 8 at 48-52; and Gary Webb, "DWB" (1999) 131:4 Esquire 118).

${ }^{31} \quad$ Cpl. Rob Ruiters of the R.C.M.P. introduced Pipeline into Canada after learning about it at a lecture on drug smuggling in Minnesota. The first Pipeline training course was set up in Manitoba in 1994 and, to date, Ruiters has trained 10,000 law enforcement officials (see the discussion of Pipeline and related training methods in $R$. v. Truong (2002), 168 (C.C.C.) (3d) 132, 2002 BCCA 315; R. v. France (2002), 1 C.R. (6th) 27 at 32, 2002 NWTSC 32; R. v. Arabi (2002), 1 C.R. (6th) 75 at 78, 2002 ABPC 51; $R$. v. Ferrari (2001), 210 Sask. R. 282, 2001 SKQB 340; R. v. Calderon, [2002] O.T.C. 450, O.J. No. 2583 (S.C.J.) (QL); and R. v. Kane (1998), 174 N.S.R. (2d) 40, 42 M.V.R. (3d) 57 (S.C.). See also David M. Tanovich, "Operation Pipeline and Racial Profiling" (2002) I C.R. (6th) 52 [Tanovich, "Operation Pipeline"]). 
experiences, individual police officers likely develop a profile over time of what the usual offender of a particular offence looks like. Based on the limited data available, it would appear that African-Canadian males are over-represented in arrests for certain offences, particularly drug offences. ${ }^{32}$ Consequently, the police likely perceive that the usual drug offender is a young, Black male. This profile is also one that has been constantly reinforced by the American experience, the media, and other aspects of our pop-culture.

In Johnson v. Halifax (Regional Municipality) Police Service, Dr. Wanda Thomas Bernard, an anti-racism expert in Nova Scotia, testified about the perpetuation of this stereotype in the media. In his reasons for concluding that Kirk Johnson, one of Canada's most well-known and successful boxers, was the victim of racial profiling, the Chair of the Nova Scotia Human Rights Commission summarized her evidence as follows:

Dr. Bernard's testimony on the powerful impact of negative media stereotypes of black males, both on white people and on black men themselves, was especially pertinent. She noted the strong tendencies in popular culture and film to focus on black men as criminals, pimps, uneducated persons, and uninvolved as fathers of their children. Her research has examined the "cool pose" that young black males sometimes adopt in response to these media portrayals, which in turn unintentionally helps to reinforce the stereotypes. The net effect of her testimony was that these negative stereotypes are widely diffused in our culture, so much so that they operate at a subconscious level, and that it requires a considerable amount of training to counteract them. ${ }^{33}$

It would take an enormous effort for this experience not to influence a police officer's decision-making process and this is likely why it has even influenced more formalized profiling such as Pipeline. Moreover, in $R$. v. Singh, it was recognized that there is no reason to believe that even a Black police officer would be immune from racial profiling. As O'Connor J. observed:

[i]t seems that any person of any race could consciously or unconsciously believe that persons of a particular race, his own or others, have a propensity toward criminal activity and thus should be targeted for attention by the police. This belief could arise from a variety of sources, including the misinformed anecdotal musings of associates, inaccurate media information or a misunderstanding of information, reports and studies etc. disseminated by police or governmental agencies. ${ }^{34}$

Similarly, Professor David Harris, the leading American scholar on this issue, has told us that "[a]ccording to the data, racial disparities in stops, searches, and the like seem to have little or nothing to do with the officer's race." 35

See Ontario Systemic Racism Report, supra note 23 at 70-105. See also R. v. Borde (2003), 8 C.R. (6th) 203 at 208-10 (Ont. C.A.); R. v. Golden, [2001] 3 S.C.R. 679 at para. 83, 159 C.C.C. (3d) 449 [Golden cited to S.C.R.] and R. v. Hamilton (2003), 8 C.R. (6th) 215 at 234-52 (Ont. S.C.J.). Johnson, supra note 18 at para. 94. See also the discussion in Frances Henry \& Carol Tator, Discourses of Domination - Racial Bias in the Canadian English-Language Press (Toronto: University of Toronto Press, 2002). 
This "usual suspect" stereotype has even led some American commentators to argue that the fact that African-Americans are over-represented in the criminal justice system for some offences makes using race to profile a reasonable and good law enforcement tactic. For example, Bernard Parks, the former Los Angeles Police Chief, who himself is Black, once stated:

[i]n my mind, it is not a great revelation that if officers are looking for criminal activity, they are going to look at the kind of people who are listed in crime reports. At some point, someone figured out that the drugs are delivered by males of his colour driving these kinds of vehicles at this time of night. This isn't brain surgery. The profile didn't get invented for nothing. ${ }^{36}$

Others have argued the because it is statistically reasonable, it should not be a prohibited form of discrimination. ${ }^{37}$

It is precisely because there is a police perception that this usual offender categorization process is based on experience and not on race that the police do not think that they are doing anything wrong when they decide, for example, to conduct a pretext vehicle stop of a Black driver. Indeed, it is why we often hear the police respond to profiling allegations as follows:

police deal with criminal profiling. From my perspective, if there is a description of individuals who have been involved in a crime ... or in certain types of crime, you would look at those people who would be suspects; ${ }^{38}$

the police can't do their job and be politically correct at the same time; ${ }^{39}$

[w] deal with the circumstances that we're presented with and we make judgments on the basis of what we do within the system, holistically, across the system. We don't look at, nor do we consider the race or ethnicity, or any of that, as factors of how we dispose of cases, or individuals, or how we treat individuals. ${ }^{40}$

We also often hear the police say that they "respond to complaints" as though suggesting that they have little or no opportunity to use racial profiling. Part of this is no doubt true. When the police are responding to a complaint and they have a description of the suspect, it is not racial profiling to use racial or ethnic descriptions as part of the investigative process. However, profiling is not, generally speaking, manifested in crime-solving or reactive policing. It typically arises in crime detection or proactive policing on our streets where the police are using their so-called "sixth sense" to identify suspicious circumstances in an effort to find contraband. Proactive policing manifested in vehicle or pedestrian stops invites racial profiling because the "usual offender" stereotype is used to turn entirely innocent events into suspicious circumstances or indicators warranting police intervention. Some of these

36. See Jeffrey Goldberg, "The Color of Suspicion" New York Times Magazine (20 June 1999).

37 Dinesh D'Souza, "Sometimes Discrimination Can Make Sense" USA Today (2 June 1999) 15A. See the discussion and persuasive criticism of this "reasonable discrimination"argument in Randall Kennedy, Race, Crime And The Law (New York: Pantheon Books, 1997) at 138-63. Toronto Police Services Board Chair Norman Gardner (Philip Mascoll, "No racial profiling by police: Gardner" Toronto Star (18 November 2002) B4 [emphasis added]). 'politically correct"' Toronto Star (11 November 2002) Al).

40 Police Chief Julian Fantino ("Fantino: 'We do not do racial profiling,"' supra note 2. See also Scot Wortley, "Profiling one source of alienation" Toronto Star (25 November 2002) B1. 
indicators and stereotypes that have triggered police scrutiny of young Black men appear to include:

- driving an expensive vehicle (the "he couldn't afford this unless he were a drug dealer" stereotype);

being out late at night (the "he must be up to no good" stereotype); ${ }^{.42}$

two or more men in a car or walking down the street wearing distinctive clothing (the "they must be a gang" stereotype);

walking in a wealthy neighborhood (the "out of place" stereotype);

standing on the street corner or present in an area purportedly known for drug trafficking (the "this must be a drug deal" stereotype); ${ }^{43}$

talking on a cell phone in a high crime area (the "he must be a drug dealer" stereotype) $;{ }^{44}$ or,

failing to make eye contact with a police officer or quickly leaving the scene of an approaching officer (the "he must have something to hide" stereotype). ${ }^{45}$

Consequently, while the police may think that differential police treatment is simply the product of good, proactive - rather than biased - policing, this conclusion is based on their perception of who is the usual offender. This subtle and often subjectively unrecognizable process is exactly what categorization, racialization, and racial profiling is all about.

Finally, the police must begin to consciously recognize the effects of using a racialized "usual offender" stereotype in law enforcement and the collateral damage caused by such a practice. ${ }^{46}$ In particular, so long as the police see the face of street level crime as Black, it will likely always remain so. Profiling is a self-fulfilling prophecy. The more that a group is targeted, the greater the likelihood that criminality will be discovered - particularly for those offences that are prevalent in society, such as drug use. The fact that the targeting reveals a disproportionate number of individuals of a particular group for a particular offence does not mean that members of that group are, in fact, the usual offenders. Indeed, the "hit rate" data (that is, the likelihood of finding drugs or other contraband following a search) that is emerging in the United States reveals that the police are just as likely and, in most cases, more likely to find contraband in stops of White individuals as compared to stops of Black individuals:

R. v. Stephen (2003), 102 C.R.R. (2d) 105, [2003] O.J. No. 634 (S.C.J.) (QL).

Troy v. Kemmir Enterprises, supra note 18. In Troy, a gas station employee called 911 to report what she thought was a drug deal or possible robbery. As it turned out, Mr. Troy was simply waiting at the gas station for a friend to direct him to his house.

R. v. Burgher, [2002] O.J. No. 5316 (S.C.J.) (QL); R. v. Snape (2002), 92 C.R.R. (2d) 372, [2002] O.J. No. 714 (S.C.J.) (QL); R. v. Peck, [2001] O.J. No. 4581 (S.C.J.) (QL); R. v. Nicely (2000), 79 C.R.R. (2d) 24, 39 C.R. (5th) 340 (Ont. C.A.); and R. v. Carty (1995), 31 C.R.R. (2d) 303, [1995] O.J. No. 2322 (Ct. Jus. Prov. Div.) (QL).

R. v. C.S. (1997), 13 C.R. (5th) 375, [1997] O.J. No. 4146 (Ct. Jus. (Prov. Div.)) (QL).

R. v. Johnson (1995), 39 C.R. (4th) 78, [1995] O.J. No. 1556 (C.A.) (QL).

These effects, including distrust of the police and the criminal justice system, have now been documented in the OHRC Report, supra note 9; see also the discussion at supra note 17. 


\begin{tabular}{|l|l|l|}
\hline Jurisdiction & Hit Rate For White Drivers & $\begin{array}{l}\text { Hit Rate For African- } \\
\text { American Drivers }\end{array}$ \\
\hline Minnesota $(2002)^{47}$ & $24 \%$ & $11 \%$ \\
\hline Rhode Island (2001-2002) & $23.5 \%$ & $17.8 \%$ \\
\hline Nevada $(2002)^{50}$ & $13.3 \%$ & $11.2 \%$ \\
\hline Iowa (2000-2002) & $42.6 \%$ & $40 \%$ \\
\hline Missouri $(2001)^{52}$ & $21.86 \%$ & $15.34 \%$ \\
\hline New Jersey $(2000)^{53}$ & $25 \%$ & $13 \%$ \\
\hline New York City $(1999)^{54}$ & $12.6 \%$ & $10.5 \%$ \\
\hline North Carolina $(1998)^{55}$ & $33 \%$ & $26 \%$ \\
\hline U.S. Customs Service $(1998)^{56}$ & $6.7 \%$ & $6.2 \%$ \\
\hline Maryland (1995/1996) & $28.8 \%$ & $28.4 \%$ \\
\hline
\end{tabular}

This data clearly demonstrates that racial profiling does not work and that it is based on a faulty premise.

\section{Changing Police Culture}

Racial profiling provides a unique challenge to the ability of institutional measures such as anti-racism training and hiring practices to change prevailing police culture because of the perceived reasonableness and unintentional elements discussed earlier. As the Nova Scotia Human Rights Commission recognized in the Johnson case:

Minnesota Statewide Racial Profiling Report: All Participating Jurisdictions, online: Institute on Race and Poverty <wwwl lumn.edu/irp/mnrpreport.html >.

Amy Farrell et al., Rhode Island Traffic Stop Statistics Act Final Report (Boston: Northeastern University Institute on Law and Justice, 2003), online: Northeastern University <www.racialprofiling analysis.neu.edu/IRJ_docs/RIFinalReport.pdf $>$ [Rhode Island Study].

In the Rhode Island Study, ibid., the comparison group was characterized as non-white, which included African-American and Hispanic drivers. A.B. 500 - Report on Study of Traffic Stops, online: Office of the Attorney General, Nevada Department of Justice www.<ag.state.nv.us/hottopics/AB500/ab500.htm>. Iowa, Criminal and Juvenile Justice Planning, An Examination of Iowa State Patrol Traffic Stops 10/00 $-3 / 02$, online: Iowa State Patrol <www.state.ia.us/government/dps/isp/Stop_Data.pdf $>$. Annual Report On 200I Missouri Traffic Stops, online: Missouri Attorney General's Office <ago. missouri.gov/racialprofiling/2001.htm\#executive>.

5.3 See Harris, supra note 8 at 79-84.

54 Ibid. The New York City percentages are actually the arrest rates per stop. In addition, the stops are pedestrian as opposed to vehicle stops. 
I also wish to address an understandable concern of officers reading this decision. If we are to be held liable for violating the Human Rights Act on the basis of unconscious stereotypes, some might say, how can we ever be sure we are acting correctly? How can we guard against something that is not conscious? Isn't if unfair to hold us to such a high standard? I think the answer to this question was given by Constable Christopher Regan at the inquiry. In response to a question about how to deal with racial stereotypes, he replied that you have to work at it. That simple answer is the essence of it. Recognizing the problem and developing techniques to deal with it, both at the personal and institutional level, are the key. Police pride themselves on being professionals and part of professionalism involves rigorous training on a wide variety of matters. Learning to recognize and deal with racism is another form of training that the police must add to their repertoire in order to continue to provide quality policing services, just as learning about domestic violence became a larger part of police training in recent years. ${ }^{58}$

Consequently, it is imperative that measures be taken to ensure that the anti-racism training, which must include anti-racial profiling training, is comprehensive and effective ${ }^{59}$ In order to accomplish this task, all police forces should be required to hire an anti-racism expert to conduct an external audit of the measures in place. In addition to training, all ranks of the force must be representative of the community. Thus, the hiring and promoting of visible minority officers must be made a priority. ${ }^{60}$ Finally, in order for any of these measures to impact on police culture, it is imperative that high-ranking police officials acknowledge the existence of racial profiling and that all forces enact a formal and written anti-racial profiling policy. Kingston and Montreal are the only forces in Canada that have such a policy. ${ }^{61}$

\section{Data Collection}

As noted earlier, the breeding ground for racial profiling is the day-to-day proactive and crime detection policing that occurs on our streets through either vehicle or pedestrian stops. These "opportunity" encounters are used by the police to find contraband such as drugs or weapons; ${ }^{62}$ to monitor the activities of "suspicious" individuals; and to generally engender respect from those groups perceived to be in need of order maintenance. ${ }^{63}$ These street level stops are a fertile ground for profiling because they are "low visibility" encounters, thereby shielding the police from having to account for their conduct. ${ }^{64}$

Johnson, supra note 18 at para. 71 .

See Recommendation \#12, OHRC Report, supra note 9 at 72.

See Recommendation \# 14, ibid. See also "Highest Ranking Black Cop Calls For More Police Diversity" (July 2000), online: Global Diversity at Work <www. diversityatwork.com/news/oct00/news_north america.html>.

Greg McArthur \& J. Pritchelt, "It's official: Racial profiling banned" The Kingston Whig-Standard (16 May 2003) 1; and Ross Marowits, "Montreal police adopt racial profiling rules" Toronto Star (23 March 2004) A17.

In a speech to the Kingston Police Services Board, Chief Bill Closs stated that 40 percent of drug arrests begin with a vehicle stop. The relevant excerpts from this speech are reproduced as text accompanying infra note 90.

See generally the discussion in Richard V. Ericson, Reproducing Order: A Study of Police Patrol Work (Toronto: University of Toronto Press, 1982) at 200-201.

In the vehicle stop context, for example, the police are entitled to stop a vehicle at any time without having to have any reason to believe or suspect that the driver has committed a traffic violation (see $R$. v. Ladouceur, [1990] I S.C.R. 1257, (1990), 56 C.C.C. (3d) 22 [Ladouceur cited to C.C.C.]). 
Consequently, one of the most significant steps that can be taken to address racial profiling is for the police to be compelled to record, either electronically or in writing, who they stop and investigate. ${ }^{65}$ This would include information such as age, gender, race, and ethnic background, where the stop takes place, the reasons for the stop, what investigative measures were taken (for example, a search) and the results. ${ }^{66}$ In addition, the police should be required to give the person stopped a ticket confirming that they were stopped, the reasons, and the name of the officer(s). The stop data should then be published on a regular basis and its collection tied to police funding.

The availability of this kind of information would serve a number of important purposes:

it would permit senior police officials and courts to monitor the performance of those officers conducting vehicle and investigative stops;

it would reveal whether or not (and to what degree) the Black, Aboriginal, or other visible minority communities are being over-policed;

it would serve to instill a sense of confidence in the Black community that police stops are carried out fairly and with good reason; and,

it might serve as a deterrent. A recent pilot project in England found that a recording obligation for all stops made officers more likely to "think twice" before acting. ${ }^{67}$

There is no question that the idea of keeping track of and reporting race-based statistics is a controversial one. Indeed, in Toronto, the police are currently prohibited from analyzing or publishing race statistics following a 1989 ban imposed by the Toronto Police Services Board. ${ }^{68}$ The Toronto prohibition came into force following a speech by then Staff-Inspector Julian Fantino on February 16, 1989 to a race-relations committee in North York, Ontario. In his speech, Fantino proclaimed that, based on statistics he had himself compiled, Blacks accounted for most of the crime in the Jane-Finch corridor and that it was this criminal element that was responsible for the "bad blood between police and Blacks."

is See Recommendations \#2, \#9, and \#10, OHRC Report, supra note 9 at 69-70. See also David M. Tanovich, "Using data to fight bias" Toronto Star (11 December 2003) A35.

66 In order to collect this information, it may not be necessary for the officer to ask the individual to identify their racial or ethnic group. As Professor Harris has pointed out "the important thing is not what race or ethnic group drivers actually belong to, but what race or ethnic group the officers think they belong to" (supra note 8 at 181-82).

67 See U.K., Home Office, Upping the Pace? An evaluation of the recommendations of the Stephen Lawrence Inquiry on stops and searches (Police Research Series, Paper 128) by Nick Bland, Joel Miller \& Paul Quinton (London: Home Office Research, Development and Statistics Directorate, 2000) at 78, online: Home Office <www.homeoffice.gov.uk.rds/prgpdfs/prs 128.pdf>.

6. The ban was imposed on 23 February 1989. The policy states "[i]t is the policy of the Board that the Board and the Force not compile or publish statistics relative to the race, colour or creed of individuals involved in criminal activity, except as approved by the Board. This policy does not affect the releasing of descriptions of suspects wanted for criminal acts." None of the other police services boards in Ontario appear to have a similar prohibition ("Minutes Of The Public Meeting of the Toronto Police Services Board," online: Toronto Police Services <www.torontopoliceserviceboard.on.ca/minutes/ 2003/030220pma\%20full.pdf>).

(9) Fantino's speech was given at a time of very strained relations between the police and the Black community particularly in light of the police shootings of Lester Donaldson in February of 1989 and Wade Lawson in December of 1988 (see "Analysis raises board hackles," supra note 2; and Royson James, "Fantino still shoots from the lip" Toronto Star (6 March 2000) GT1). 
As the Fantino experience demonstrates, one must always be cognizant of the optics and ethics of compiling race-based statistics. Statistics can be misleading and may serve to further stereotype a particular community. Indeed, part of what appears to drive racial profiling is a belief that a "usual offender" profile can be determined based on arrest and conviction statistics. Statistics can also be easily manipulated and used for an improper purpose. While these concerns must inform and ensure that the data collection process is conducted in a fair manner, they do not, on balance, support a prohibition on keeping track of who the police stop. In approaching this issue, one must compare apples to apples. The historical problem with race statistics is that they have only given us part of the picture: who is arrested, convicted, and sentenced. This data is misleading and very susceptible to distortion and abuse because, to the extent that it shows that certain groups are over-represented for certain offences, it cannot tell us whether that over-representation is due to greater criminality in the group or whether it is due to over-policing and targeting or to other systemic factors.

Race-based stop data, on the other hand, is less controversial than arrest data for three reasons. First, it is less misleading because the focus is on police surveillance and not on who gets caught - a fact that may, as noted earlier, be the product of the former. Second, the purpose of stop data is to identify the existence and scope of a serious social problem. ${ }^{70}$ Finally, in England and most of the United States, there is now a stop data collection requirement and its implementation was vigorously supported by the Black community. Data collection was also endorsed as a means of addressing racial profiling by the OHRC in its report on racial profiling. ${ }^{71}$

Of course, sufficient safeguards must be taken to protect the integrity of the process. The data collection design should be left to the experts: university professors or statisticians. ${ }^{72}$ Anti-racism experts should also be involved. Steps must be put in place to ensure that the police are not fudging or falsifying the data. Safeguards could include the installation of video-cameras in all police cars, ${ }^{73}$ a requirement that all stops be called into the dispatch, or

This would explain why there appears to be a growing swell of support for stop data collection amongst the Black community. See, for example, the discussion in Jack Lakey, "Groups endorse racial statistics" Toronto Star (9 October 2003) B1; and Scott Anderson, "Minorities warm up to race-based stats" Now On Newsfront (29 June 2000), online: Now on Newsfront $<$ www.nowtoronto.com/issues/2000-06-29/ newspread3.html $>$.

See discussion at supra note 65 and accompanying text.

Many of the methodological issues surrounding data collection are discussed in John C. Lamberth, $A$ Multijurisdictional Assessment of Traffic Enforcement and Data Collection in Kansas (Washington: Police Services, 2003), online: Northeastern University <www.racialprofiling analysis.neu.edu/bg jurisdictions.php>. For more information about Dr. Lamberth, see online: Lamberth Consulting $<$ www.lamberthconsulting.com/research_articles.asp > . Methodological issues are also discussed in United States, Department of Justice Office of Community Oriented Policing Services, How To Correctly Collect and Analyze Racial Profiling Data: Your Reputation Depends on it, by Joyce McMahon et al., online: U.S. Department of Justice <www.cops.usdoj.gov/mime/open. pdf?Item=770>; and Harris, supra note 8 at 175-92.

In Ontario, the Ontario Provincial Police have announced a pilot project to install video cameras in 38 cruisers in Kenora and Toronto (see OHRC Report, supra note 9 at 13 and Recommendation \#15 at 72. See also "Ontario forges ahead with cameras in police cruisers" The Globe And Mail (10 December 2003), online: The Globe and Mail <www.theglobeandmail.com>). In South Dakota, a resolution encouraging the use of video cameras at all traffic stops was enacted on 12 February 2002, and in Minnesota and Missouri, there are grant programs in place for video camera installation in police vehicles (see Racial Profiling Data Collection Resource Center at Northeastern University, online: Northeastern University < www.racialprofilinganalysis.neu.edu/bg_jurisdictions.php>)). 
a requirement, as in England, that the police issue a written confirmation that the individual was stopped, the reasons, and the name of the officer. While the data has to be collected by the police, its analysis and publication should be done by an independent third party, such as the Racial Diversity Secretariat proposed by the Ontario Human Rights Commission. ${ }^{74}$ Finally, it is important to ensure that the Black community and organizations such as the Ontario Human Rights Commission have a voice in the manner and scope of the data collection process.

Before leaving this issue, I want to briefly look at data collection in England, the United States, and Canada.

\section{A. ENGLAND}

In England, various acts authorize the police to detain and search individuals whom police reasonably suspect are in possession of contraband. ${ }^{75}$ This stop and search power is much broader than the current powers in Canada, which only permit the police to conduct a frisk search for weapons during an articulable cause detention. ${ }^{76}$ In an effort to safeguard against abuses of this power, Code of Practice A (Code of Practice For The Exercise By Police Officers Of Statutory Powers Of Stop And Search) of the Police and Criminal Evidence Act 1984 (PACE) was enacted on 1 January $1986 .^{77}$

Code A's current version, in force as of 1 April 2003, includes the following antidiscriminatory provisions:

\section{Section A:1.1}

Powers to stop and search must be used fairly, responsibly, with respect to people being searched and without unlawful discrimination. The Race Relations (Amendment) Act 2000 makes it unlawful for police officers to discriminate on the grounds of race, colour, ethnic origin, nationality or national origins when using their powers.

\section{Section A:2.2}

Reasonable grounds for suspicion depend on the circumstances in each case... Reasonable suspicion can never be supported on the basis of personal factors alone without reliable supporting intelligence or information or some specific behaviour by the person concerned. For example, a person's race, age, appearance, or the fact that the person is known to have a previous conviction, cannot be used alone or in combination with each other as the reason for searching that person. Reasonable suspicion cannot be based on generalizations or stereotypical images of certain groups or categories of people more likely to be involved in criminal activity.

See Recommendation \#1, OHRC Report, supra note 9 at 68.

75 For example, drugs under the Misuse of Drugs Act (U.K.), 1971, c. 38, s. 23; offensive weapons (e.g. bladed or sharply-pointed articles) and stolen merchandise under the Police and Criminal Evidence Act, (U.K.), 1984, c. 60, s. 1; and firearms under the Firearms Act (U.K.), 1968, c. 27 , s. 47. power seems to be growing in scope: see R. v. Mann (2002), 5 C.R. (6th) 305, 166 Man. R. (2d) 260 (C.A.) (leave to appeal to S.C.C. granted [2002] S.C.C.A. No. 484); and R. v. Cooke (2002), 2 C.R. (6th) 35,171 B.C.A.C. 177. 
In addition, ss. A:4.3-A:4.4 require the police to record the following information about all individuals and vehicles that are searched pursuant to the exercise of a statutory stop and search power:

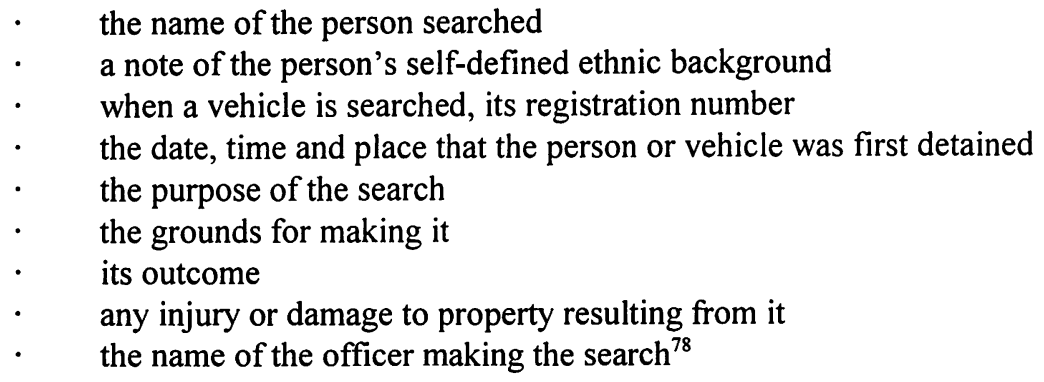

Finally, s. A:4.2 obligates the officer to give a copy of the record to the individual searched.

In England, this search data is now published on a yearly basis pursuant to s. 95 of the Criminal Justice Act $1991^{79}$ and it has been instrumental in revealing the scope of disproportionate race-based stops and searches in England and Wales ${ }^{80}$ Not surprisingly then, the issue of racial profiling became a focal point of the Stephen Lawrence Inquiry in 1999. On 22 April 1993, Stephen Lawrence, a young Black man, was stabbed to death by a group of White men at a bus stop in Eltham, southeast of London. Prior to his killing, one of the murderers was overheard saying "what what nigger." A police investigation by the Metropolitan Police (the Met) failed to bring the killers to justice. Following an investigation launched by the family, five suspects were identified. A private prosecution of three of the men failed. Allegations of corruption and institutional racism within the Met led to the launching of an inquiry by the Labour government. Sir William Macpherson of Cluny was appointed Commissioner. ${ }^{81}$

In his final report, Macpherson made the following findings about racial profiling in England:

45.8 If there was one area of complaint which was universal it was the issue of "stop and search." Nobody in the minority ethnic communities believes that the complex arguments which are sometimes used to explain the figures as to stop and search are valid. In addition their experience goes beyond the formal stop and search figures recorded under the provisions of the Police and Criminal Evidence Act, and is conditioned by their experiences of being stopped under traffic legislation, drugs legislation and so called 'voluntary' stops. It is not within our terms of reference to resolve the whole complex argument on this topic. Whilst there are other factors at play we are clear that the perception and

Ibid. There are some safety exceptions that exempt an officer from having to comply with some or all of these recording obligations.

79 (U.K.), 1991, c. 53.

80 This data was referred to earlier at note 9. See also, "Police still search more black people" $B B C$ News (7 November 2002), online: BBCNews <http://news.bbc.co.uk/1/hi/uk/2413979.stm>; and "Troubled history of stop and search" BBC News (7 November 2002), online: BBC News <http://news.bbc. co.uk/1/hi/uk/2246331.stm>.

81 See Dominic Casciani, "Q\&A: Lawrence murder, ten years on" BBC News (22 April 2003), online: $\mathrm{BBC}<$ news.bbc.co.uk/2/hi/uk_news/2965399.stm>. 
experience of the minority communities that discrimination is a major element in the stop and search problem is correct...

45.10 It is pointless for the police service to try to justify the disparity in these figures purely or mainly in terms of the other factors which are identified. The majority of police officers who testified before us accepted that an element of the disparity was the result of discrimination. This must be the focus of their efforts for the future. Attempts to justify the disparities through the identification of other factors, whilst not being seen vigorously to address the discrimination which is evident, simply exacerbates the climate of distrust. ${ }^{82}$

These findings and concerns led Macpherson to issue the following recommendation with respect to the recording of all stops and not just stops that resulted in searches:

\section{Recommendation 61}

That the Home Secretary, in consultation with Police Services, should ensure that a record is made by police officers of all "stops" and "stops and searches" made under any legislative provision (not just the Police and Criminal Evidence Act). Non-statutory or so called "voluntary" stops must also be recorded. The record to include the reason for the stop, the outcome, and the self-defined ethic origin of the person stopped. A copy of the record shall be given to the person stopped. ${ }^{83}$

Recommendation 61 is gradually being incorporated into police practice. ${ }^{84}$ As of April 1, 2003, six police forces across Britain will be required to comply with the recommendation using the following definition of a stop: "[w]hen an officer requests a person in a public place to account for themselves - their actions, behaviour, presence in an area or possession of anything." 85 The information is recorded on a hand-held computer and individuals have the option of receiving the record by text, e-mail, or in the mail. ${ }^{86}$

\section{B. The UNITED STATES}

In the United States, 17 states have passed legislation or an executive order compelling the police to collect data on who they stop. ${ }^{87}$ Eleven states have pending data collection

82 Macpherson Report, supra note 8 at paras. 45.8-45.10 [emphasis in original].

83 Ibid. at Chapter 47 - para. 61 . Recommendation 61 was studied and analyzed in U.K., Home Office, Upping the Pace? An evaluation of the recommendations of the Stephen Lawrence Inquiry on stops and searches, supra note 66.

84 Many of the amendments to the 2003 version of Code $A$ discussed earlier were also enacted as a result of the findings of the Stephen Lawrence Inquiry.

85 It is predicted that Recommendation 61 could be in force across London by September 2004. See “'Receipts' record police stops" $B B C$ News (1 April 2003), online: <http://news.bbc.co.uk/ 2/hi/uk_news/england/2903377.stm>.

86 See "Police receipts to cut racism claims" BBC News (1 April 2003), online: BBC <http://news.bbc. co.uk/2/hi/uk_news/wales/2907021.stm>; and "'Receipts' record police stops," ibid.

87 Colorado, Connecticut, Illinois, Kansas, Kentucky (executive order), Louisiana, Maryland, Massachusetts, Missouri, Nebraska, Nevada, North Carolina, Rhode Island, South Dakota, Texas, Utah and Washington (see Racial Profiling Data Collection Resource Center at Northeastern University, online: Northeastern University <www.racialprofilinganalysis.neu.edu/bg jurisdictions.php $>$ ). Some states have placed time limits on the data collection. For example, in Massachusetts, the time period for data collection was from 1 April 2001 until 31 March 2002 (ibid.). 
legislation. ${ }^{88}$ Jurisdictions in another 19 states (including some with pending legislation) collect some form of data on a voluntary basis. ${ }^{89}$ Unlike in England, however, most of the U.S. data collection relates only to vehicle stops. ${ }^{90}$

\section{CANADA}

In Canada, the only police force that has implemented a mandatory data collection process for police stops is the Kingston Police Service. ${ }^{91}$ These bold and courageous moves were prompted by Chief of Police Bill Closs' willingness to address recent allegations of racial profiling in Kingston in a thoughtful and intelligent fashion. In his remarks to the Kingston Police Services Board on May 15, 2003, Chief Closs stated:

Policing is ... not always easy because one of the most important ideas in modern criminology, and one that has pretty much revolutionized policing in the last 25 years, is the belief that a good way to prevent serious crime and motor vehicle collisions is through proactive policing - officers should be watchful, pay attention to anything, respond to reports of suspicious activity - check people and vehicles, often, especially in high crime areas, unusual locations, particular times or follow your experience and intuition. By way of example approximately 40 per cent of all drug arrests begin as a traffic stop, the same way pulling over a car for as an example, a driver's license check, remains an effective way of apprehending drunk drivers.

... At issue is whether the race, ethnicity, gender, economic status or age of the person stopped or checked is the only-sole reason for initiating the stop. This practice is commonly referred to as "profiling" and lately we hear it referenced most often as racial profiling. While my officers and this service have never condoned this practice, the publicity generated by the allegations has cast a shadow over the Kingston Police.... There is a perception by a few, that the Kingston Police profile on the basis of race. Racial profiling is not institutionalized in our service, but the perception cannot be ignored and police must respond to the reality or perception by going beyond denial and patronization. I don't want any person living in our community to change their behaviour as to avoid being stopped or pulled over by police....

What I am presenting today is a general order on unlawful profiling or bias-based policing.... There are those who believe an order is not necessary as policies on discrimination, race relations and harassment are sufficient. I do not agree because it fails to respond to the perception of bias policing... Today we are setting an even higher standard for Kingston Police officers in that they are being asked to acknowledge and understand the need for a proactive order that recognizes the existence of unlawful profiling/bias-based policing and the need to prevent it. ${ }^{92}$

Alabama, Georgia, Indiana, Iowa, Michigan, New York, Ohio, Oklahoma, Pennsylvania, South Carolina and Virginia (see Racial Profiling Data Collection Resource Center at Northeastern University, ibid.). Alabama, Arizona, California, Delaware, Florida, lowa, Michigan, Minnesota, Montana, New Mexico, New York, Ohio, Oregon, Pennsylvania, South Carolina, Tennessee, Virginia, West Virginia and Wisconsin (see Racial Profiling Data Collection Resource Center at Northeastern University, online: Northeastern University <www.racialprofilinganalysis.neu.edu/bg_jurisdictions.php>).

Kansas and Utah are two jurisdictions where all stops are recorded (see Racial Profiling Data Collection Resource Center at Northeastern University, online: Northeastern University <www.racialprofiling analysis.neu.edu/bg_jurisdictions.php $>$ ).

The collection period commenced October 1,2003 and is scheduled to last approximately one year (General Order Vol. I-B-74K (Unlawful Profiling/Bias-Based Policing); see also Sonia Verma, "Kingston police to gather race data" Toronto Star (19 July 2003) Al and G. McArthur, "How Kingston Police will keep stats on race" The Kingston Whig-Standard (19 July 2003) 1).

McArthur \& Pritchett, supra note 62. 
Chief Closs' efforts have been praised in the House of Commons, where the Honourable Jean Augustine observed:

Mr. Speaker, the Government of Canada considers the selective treatment of individuals based solely on their race or on their ethnic characteristics as unacceptable. Today in the newspapers we read that Kingston, Ontario police chief Bill Closs has shown some leadership in providing guidelines and setting light on the issue of racial profiling and I commend him for this. ${ }^{93}$

At the federal level, a data collection project is currently being implemented by Canada Customs that will identify the scope of the profiling of both Arab- and African-Canadians. In a settlement agreement in the racial profiling case of Pieters $v$. Canada (Department of National Revenue), ${ }^{94}$ Canada Customs agreed to conduct a pilot project to keep track of the race and ethnicity of individuals subjected to secondary inspection at ports of entry. ${ }^{95}$

\section{Revamping the Public Complaints System}

Formal measures must also be taken to improve police accountability. One of the ways in which to monitor the performance of a police service and to identify and address systemic problems is through a properly run public complaints process. The current system in Ontario has a number of serious problems. ${ }^{96}$ It is not, nor is it perceived to be, objective or independent. ${ }^{97}$ This lack of independence is very problematic. The public must feel confident that they have a place to complain about police misconduct and that their complaints will be treated fairly. This is particularly true for an issue as highly charged and sensitive as racial profiling.

No one should be surprised that a member of the Black community in Toronto would not want to file a racial profiling complaint in these circumstances, particularly given Chief Fantino's public statements about profiling. This is very unfortunate. In the criminal justice system, Parliament and our courts have spent the last decade trying to make the system more sensitive to victims. To that end, a number of measures have been taken to reduce revictimization and to promote the reporting of incidents, particularly in the sexual assault context. This same philosophy needs to be incorporated into the public complaints process.

House of Commons Debates (16 May 2003), online: Edited Hansard <www.parl.gc.ca/37/2/parlbus/ chambus/house/debates/104_2003-05-16/han104_1150-E.htm>.

94 (2001), C.H.R.R. Doc. 01-201 (C.H.R.T.), online: Canadian Human Rights Reporter <www.cdn-hrreporter.ca>.

95 See John Saunders, "Traveller wins customs fight" The Globe and Mail (6 February 2002) A1; and Paul Waldie, "Customs to gather racial data to see if officers use racial profiling" The Globe and Mail (16 December 2002) Al.

Ontario Systemic Racism Report, supra note 23 at 359. See also the discussion in Scott Simmie \& Jennifer Quinn, "Complaint system under fire" Toronto Star (21 November 2002) B1. In his review of the system, City of Toronto auditor Jeffrey Griffiths made 27 recommendations (see John Duncanson "Police complaints overhaul urged" Toronto Star (23 October 2002) B3). Earlier criticisms of the complainants process can be found in Michelle Williams, "Deputation to the Metropolitan Toronto Police Services Board Regarding the Implementation of the Police Complaints Process," online: African Canadian Legal Clinic <www.aclc.net/submissions/policecomplaint.html >; and Tammy Landua, Public Complaints Against the Police: A View From Complainants (Toronto: Centre of Criminology, 1994). Even Chief Fantino appears to recognize the problems with the current system (see Peter Small, "'Zero tolerance' on racial profiling: Fantino" Toronto Star (21 November 2002) A1).

For example, too much of the current vetting and investigative functions are left to the Chief of Police. 
Another problem with the Ontario system is accessibility. Victims of profiling need to know who to call. In the United States, the American Civil Liberties Union started a large scale publicity campaign aimed at creating a database of profiling complaints. Large billboards were posted identifying the problem and providing a toll free phone number to call to report an incident. This could be done in Toronto and other areas in relation to the public complaints system. In addition, the following recommendation should be given serious consideration:

10.6 The Commission recommends that the Ministry of the Solicitor General and Correctional Services, in consultation with the community agencies -

a) formulate a Public Complaints Policy Statement and distribute it widely among their local communities. This statement should emphasize the function of complaints not only in responding to specific incidents, but also in helping to identify and resolve systemic problems.

b) develop a comprehensive public complaints database that includes categories that would allow the police to monitor complaints about police stops of black or other racialized people. The database should be used to generate quarterly reports of patterns and trends.

c) fund education on formal and informal police complaint mechanisms. ${ }^{98}$

\section{ANti-Racial Profiling Legislation}

Politicians at both the provincial and federal levels must assume a leadership role on this issue. ${ }^{99}$ Legislation needs to be enacted at both levels of government prohibiting the use of racial profiling by the police and other state and security-related officials. Such legislation would send an important message to the police; the Black, Aboriginal, and Arab communities and the public that such a practice will not be tolerated. It would also reflect a recognition by Parliament and the provincial Legislatures that profiling is a problem.

In addition to making it unlawful, federal and provincial legislation should make it mandatory for the police to maintain cameras and global positioning systems in their vehicles and to establish a stop data collection scheme. Such legislation should also tie police functioning to compliance. In February 2004, Libby Davies, a New Democratic MP from Vancouver, introduced a private member's Bill entitled An Act to Eliminate Racial Profiling ${ }^{100}$ to address many of these issues. This is a good start. It is also time for Parliament to amend the Criminal Code ${ }^{101}$ and make racial profiling a criminal offence with a mandatory minimum sentence in cases where death or serious bodily harm result.

An anti-profiling law could also provide a jurisdictional basis for aggrieved individuals to seek a civil remedy in court. ${ }^{102}$ In the debate surrounding the enactment of Bill C-36, the

Ontario Systemic Racism Report, supra note 23 at 360 [emphasis in original].

There now appears to be some political momentum. At the federal level, for example, Prime Minister Martin recently spoke out against racial profiling in the domestic and terrorism contexts (see Susan Delacourt, "'Not our Canada,' Martin says" Toronto Star (6 April 2004) A1; see also the Ontario situation discussed at supra note 15 ).

See online: New Democratic Party <www.canadians4justice.ca>; Bill C-476 can be found online: Government of Canada <www.parl.gc.ca/PDF/37/3/parlbus/chambus/house/bills/private/c-476_1.pdf> R.S.C. 1985 , c. C-46. See the discussion in Kent Roach, "Hard to prove racial profiling" Toronto Star (25 November 2002)
B2. 
Anti-Terrorism Act, ${ }^{103}$ Professors Kent Roach and Sujit Choudhry proposed that the Criminal Code be amended to include a ban on racial and ethnic profiling in both the terrorism and non-terrorism contexts. This amendment was rejected. ${ }^{104}$ Professor Choudhry described the proposed amendment as follows:

If racial and ethic profiling has occurred, this amendment would allow a court to award any remedy that is appropriate and just in the circumstances, including damages, injunctions, declarations and costs. The Court may also refer the matter to a human rights commission that has jurisdiction with respect to the particular law enforcement agent or agency....

Finally, to strengthen compliance with the ban on profiling, this amendment would require the attorney-general of Canada and every province to publish an annual report on racial profiling. The report shall include steps taken to ensure that law enforcement officers and agencies not engage in profiling, and data that is sufficiently detailed to determine whether law enforcement agencies are engaged in racial and ethnic profiling. ${ }^{105}$

In the United States, a number of states have enacted laws prohibiting racial profiling. ${ }^{106}$ In New Jersey, racial profiling is now a criminal offence. ${ }^{107}$ Perhaps the most ambitious American anti-profiling law is still waiting to be passed - The End Racial Profiling Act of 2004. ${ }^{108}$ This federal Act was introduced with strong bipartisan support in the Senate and the House of Representatives on 26 February 2004. The proposed Act makes important findings about the existence, unreliability, and harmful effects of profiling. For example, s. 7 notes that "[s]tatistical evidence from across the country demonstrates that racial profiling is a real and measurable phenomenon." In addition, in the context of profiling in the "war against drugs," s. 11 observes that:

(A) black women who were United States citizens were 9 times more likely than white women who were United States citizens to be x-rayed after being frisked or patted down [by Customs Officials];

(B) black women who were United States citizens were less than half as likely as white women who were United States citizens to be found carrying contraband;

(C) in general, the patterns to select passengers for more intrusive searches resulted in women and minorities being selected at rates that were not consistent with the rates of finding contraband.

S.C. 2001 , c. 41

Sujit Choudhry, "Laws needed to ban racial profiling" Toronto Star (25 November 2002) B2.

Ibid. See also the discussion in Sujit Choudhry \& Kent Roach, "Racial and Ethnic Profiling: Statutory Discretion, Constitutional Remedies, and Democratic Accountability" (2003) 41 Osgoode Hall L. J. 1. For example, Arkansas, Connecticut, Illinois, Louisiana, Montana, Nebraska, Nevada, New Jersey, Oklahoma, Utah and West Virginia. The Governors of Wisconsin and Wyoming have issued executive orders banning racial profiling (see Racial Profiling Data Collection Resource Center at Northeastern

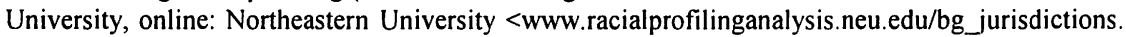
php>; and "CPA News May 2003," online: Centre for Policing Alternatives <www.cfpa.org/cpa/ publications/policynews/ 05-03.htm>).

7 Under this statute, a person must commit two acts of profiling before he or she can be found guilty. Officers who forge documents are also criminally liable. Up to five years imprisonment and/or $\$ 15,000$ fine can be imposed. The penalty increases to 10 years imprisonment if someone is injured (see "New Jersey Outlaws Racial Profiling," online: CBS 2 <cbsnewyork.com/siteSearch/topstoriesny_story_ 073121221.html>).

U.S., H.R. 3847, 108th Cong., 2004 
Similarly, in the context of the "war against terrorism," s. 15 forcefully concludes:

In the wake of September 11, 2001 terrorist attacks, as many Arabs, Muslim, Central and South Asians, and Sikhs, as well as other immigrants and Americans of foreign descent, were treated with generalized suspicion and subjected to searches and seizures based on religion and national origin, without trustworthy information linking specific individuals to criminal conduct. Such profiling has failed to produce tangible benefits, yet has created a fear and mistrust of law enforcement agencies in these communities. ${ }^{109}$

The $A c t$ also creates a racial profiling tort and sets out the mandatory protocols that federal law enforcement agencies must enact to combat racial profiling, including data collection. In addition, it ties funding with compliance.

\section{STIMUlating LAW SUITS}

Aggrieved individuals must be encouraged to take their cases to court. Racial profiling class-action law suits have been effective in the United States in bringing about systemic change and providing for monetary damages. ${ }^{110} \mathrm{With}$ the emergence of contingency fees in Ontario, more lawyers may now be prepared to entertain racial profiling lawsuits. ${ }^{11}$ The willingness of the bar to accept profiling cases may also increase if judges were prepared to relax or forgo the awarding of costs should the lawsuit not succeed. Anti-profiling legislation and enhanced Charter standards discussed in Part VIII will also serve to stimulate civil actions.

\section{Stimulating LAW REFORM}

Finally, courts have an important role to play. In "Using The Charter To Stop Racial Profiling," 112 I suggested the following steps that courts can take in this area: ${ }^{113}$

\section{A. Recommendation \#1: The Supreme Court of Canada Should OVERRULE R. V. LADOUCEUR}

Racial profiling is most commonly manifested in pretext vehicle stops. In Ladouceur, ${ }^{114}$ the Supreme Court of Canada effectively gave the police a racial profiling writ of assistance as it refused to place any meaningful limit on the ability of the police to conduct a vehicle stop. ${ }^{115}$ Following Ladouceur, as long as a police officer's primary purpose is to conduct a routine traffic check, the officer can stop a car without the slightest need for suspicion that

109

The critical issue in Canada will be whether racial profiling litigants will meet the certification requirements under the relevant Class Proceedings Act. See the discussion of this issue and the development of class actions in Canada in Hollick v. Toronto (City), [2001] 3 S.C.R. 158, (2001), 205 D.L.R. (4th) 19; Western Shopping Centres Inc. v. Dutton, [2001] 2 S.C.R. 534, (2000), 94 Alta. L.R. (3d) 1; and Carom v. Bre-X Minerals Ltd. (2000), 51 O.R. (3d) 236, 196 D.L.R. (4th) 344 (C.A.).

III See McIntyre Estate v. Ontario (A.G.) (2002), 61 O.R. (3d) 257, 218 D.L.R. (4th) 193 (C.A.).

112 Tanovich, "Using the Charter," supra note 17 at 167-68, 178-86.

113
Supra note 64.

In Ladouceur, ibid., a slim majority of the Court (5-4) held that while the random stop power violated s. 9's guarantee against arbitrary detention, it was a necessary and reasonable limit under s. 1 of the Charter in order for the police to properly protect us from the consequences of unfit vehicles and unlicenced or intoxicated drivers. 
the driver has violated a traffic (or criminal) law. ${ }^{116}$ Not surprisingly, this broad and virtually unreviewable discretionary power serves as an open invitation to conduct race-based stops. Indeed, this form of profiling has become so pervasive in the Black community that the phrase "DWB" (driving while Black) has been coined to describe why people are actually being pulled over by the police. Consequently, it is time for the Supreme Court of Canada to overrule Ladouceur and to impose a probable cause standard for all traffic stops. ${ }^{117}$

\section{B. RECOMMENDATION \#2: COURTS MUST FACTOR IN THE RELEVANT Social Context of Racial Profiling When Determining the Charter Standards to Guide Police Powers of Stop AND SEARCH}

In determining the relevant Charter standards to guide the police powers to stop and search individuals under ss. 8 and 9, courts must factor in the relevant social context of racial profiling. This factoring in can be done by using s. 15(1) principles to incorporate an equality-oriented analysis into the determination and application of Charter standards. Such an approach is not without precedent. In Golden, for example, the Supreme Court applied an equality analysis when determining the scope of the common law power of the police to strip search individuals following their arrest. Justices Iacobucci and Arbour, for the majority, held:

we believe it is important to note the submissions of the ACLC and the ALST that African Canadians and Aboriginal people are overrepresented in the criminal justice system and are therefore likely to represent a disproportionate number of those who are arrested by police and subjected to personal searches, including strip searches.... As a result, it is necessary to develop an appropriate framework governing strip searches in order to prevent unnecessary and unjustified strip searches before they occur. ${ }^{118}$

By recognizing equality issues in the interpretation of s. 9, courts will become more alive and sensitive to the concerns of visible minorities. Equality concerns can be reflected, for example, by recognizing that police stops and searches of Black citizens are far more intrusive than stops of other groups, that they have imposed disproportionate burdens on the Black community, and that racial profiling has led to distorted policing.

\section{Recommendation \#3: The Crown Should Bear the OnUS UNDER SECTION 9 OF ESTABLISHING ON A BALANCE OF Probabilities that a Vehicle StOP Was not the Result of Racial Profiling}

One of the problems with the ability of the current s. 9 standards to control racial profiling in the vehicle stop context is the difficulty of proving that race played a role in the stop. As Morden J.A. observed in Brown: that a traffic law has been violated: Delaware v. Prouse, 440 U.S. 648 (1979).

117 This will not, of course, be sufficient by itself because, as is evident in the United States, pretext stops and racial profiling remain a problem even with this probable cause standard. 
A racial profiling claim could rarely be proven by direct evidence. This would involve an admission by a police officer that he or she was influenced by racial stereotypes in the exercise of his or her discretion to stop a motorist. Accordingly, if racial profiling is to be proven it must be done by inference drawn from circumstantial evidence.

The respondent submits that where the evidence shows that the circumstances relating to a detention correspond to the phenomenon of racial profiling and provide a basis for the court to infer that the police officer is lying about why he or she singled out the accused person for attention, the record is then capable of supporting a finding that the stop was based on racial profiling. I accept that this is a way in which racial profiling could be proven. ${ }^{119}$

However, even making a circumstantial case will likely require a Herculian effort in the Ladouceur context, since a police officer will be able to simply mask his or her true intent by either claiming that the driver committed a traffic offence or that the purpose of the stop was to confirm that the driver had a valid driver's licence. ${ }^{120}$

$S i n g h^{121}$ reveals just how difficult establishing an instance of racial profiling will be, particularly if trial judges are unwilling to scrutinize an officer's evidence with the suspicion that is often required. In Singh, a Black police officer was travelling in the opposite direction from a vehicle with three young men of colour. It was late at night in an area of Brampton, Ontario with a high incident of criminal activity. The officer made a U-turn and then stopped the vehicle because he suspected that the backseat passenger was not wearing his seatbelt. One of the occupants testified that when he saw the police car make a U-turn, he advised the driver to stay within the speed limit and made sure that everyone was wearing a seat belt. Given the contraband in the car, he did want to give the officer any reason to pull them over.

Once the officer got to the car, he smelled a strong odour of marijuana and arrested all three occupants. Searches incident to those arrests revealed drugs and firearms. Notwithstanding the following suspicious circumstances suggestive of racial profiling, the claim failed:

the officer's conduct suggested that he had become fixated on this vehicle after it had passed him in the opposite direction. This included making a "u-turn", following, and eventually catching up to the vehicle; the time of night and the location of the stop (a so-called "high crime area"); the officer conducted a licence plate check while following the car; the officer pulled up alongside the vehicle to look inside before he stopped it;

Brown, supra note 10 at 254. See Tanovich, "Using the Charter," supra note 17 at 169-72; and Tanovich, "Operation Pipeline," supra note 31 at 53-55 for a discussion of how to build a circumstantial case that the detention corresponded with the phenomenon of racial profiling.

There will also be similar problems of proof even in the R. v. Simpson (1993), 12 O.R. (3d) 182, 79 C.C.C. (3d) 482 (Ont. C.A.) [Simpson] investigative detention context, which requires the Crown to establish reasonable suspicion that the individual is implicated in criminal activity in order for the detention to be a reasonable one under s. 9 of the Charter (see e.g. R. v. Wilson, [2003] O.J. No. 4465 (S.C.J.) (QL)).

121 Supra note 34. See David M. Tanovich, “Annotation” (2004) 15 C.R. (6th) 289. 
- the justification for the stop was the officer's belief that a rear seated passenger was not wearing his seat belt;

- he called for back-up; and

- upon smelling marijuana, he intended to immediately arrest all three occupants for possession even though he had no basis for knowing whether there was any marijuana in the car or who, if anyone, was in possession of it.

Unless our courts are prepared to take a more proactive approach to addressing claims of racial profiling, few litigants will experience meaningful access to justice. One such approach is to reverse the s. 9 onus of proof in those jurisdictions like Ontario where courts have recognized the existence of racial profiling by the police or where judicial notice of profiling can be taken. This reversal of the onus would shift the evidentiary burden to the Crown to establish, on a balance of probabilities, that a vehicle stop of a Black driver was not motivated by race. ${ }^{122}$ This approach resembles, in many ways, the current challenge for cause process where evidence of widespread racism is deemed to rebut the common law presumption that all prospective jurors are unbiased, requiring all jurors to be pre-screened under s. 638(1)(b) of the Criminal Code. ${ }^{123}$

This reverse onus is consistent with equality and fairness principles as well as with precedent and policy. Our courts have imposed a number of shifting burdens in the Charter context, the most notable being in s. 8. ${ }^{124}$ As a matter of policy, the Crown is "functionally responsible for the maintenance of the administration of justice." 25 Since the police are part of the administration of justice, the Crown should be held accountable for police misconduct such as racial profiling. Moreover, the Crown has access to far more information that could shed light on the intent of the police officer than does an accused person. ${ }^{126}$

122 For a discussion of how this burden might be satisfied, see Tanovich, "Using the Charter," supra note 17 at $181-83$.

12. Supra note 101; see R. v. Parks (1993), 15 O.R. (3d) 324, 84 C.C.C. (3d) 353 (C.A.); and Williams, supra note 25.

124 Once the accused establishes that a search was conducted without a warrant, the onus shifts to the Crown, under s. 8, to establish on a balance of probabilities that the search was authorized by law, that the law is reasonable, and that the search was conducted in a reasonable manner (see $R$. v. Collins, [1987] 1 S.C.R. 265 at para. 23, 33 C.C.C. (3d) 1 at 14). Indeed, the Supreme Court of Canada has frequently resorted to shifting burdens in Charter and non-Charter contexts (see e.g. R. v. Harper, [1994] 3 S.C.R. 343 at paras. 11-16, 92 C.C.C. (3d) 423; and R. v. Stillman, [1997] 1 S.C.R. 60-7 at paras. 102-106, 113 C.C.C. (3d) 321 in the context of s. 24(2); and R. v. Daviault, [1994] 3 S.C.R. 63 at para. 63, 93 C.C.C. (3d) 21 ; and R. v. Stone, [1999] 2 S.C.R. 290 at paras. 171-92, 134 C.C.C. (3d) 353 in the context of non-insane automatism).

125 John Sopinka, Sidney N. Lederman \& Alan W. Bryant, The Law of Evidence in Canada, 2d ed. (Toronto: Butterworths, 1999) at 420.

126. There appears to be some support for this reverse onus idea. It was endorsed by Trafford J. of the Ontario Superior Court of Justice at a 2002 conference in Toronto (see Tracy Tyler, "Some racial profiling illegal, judge says" Toronto Star (26 October 2002) B4). 


\section{Recommendation \#4: All Street level Criminal INVESTIGATIONS SHOULD BE DEEMED A DETENTION FOR SECTION 9 PURPOSES}

To date, courts have applied a very narrow s. 9 test of detention when looking at street level pedestrian encounters with the police. ${ }^{127}$ Testimony from the police officer that he or she asked or advised the individual "to come over" or "we want to speak to you" or "where are you guys headed" or "what are you doing here" or "what's your name" too often gets characterized as a request rather than a demand. This is problematic because it fails to take into account the reality that race plays a role in the psychological impact of such requests. In addition, a narrow approach serves to insulate potential incidents of racial profiling from Charter scrutiny.

Consequently, all street level police encounters targeting an individual for a criminal investigation should be deemed a detention under s. 9. This will ensure that all individuals and particularly members of those groups subjected to profiling will feel, and be, free to walk our streets without fear that they will be hassled by the police. ${ }^{128}$ Under this approach, the police would be entitled to conduct street level investigations of suspects, but only if those investigations complied with the requirements laid out in Simpson ${ }^{129}$ and its progeny, namely, a reasonable suspicion that the individual is implicated in criminal activity.

R. v. Griffiths ${ }^{130}$ marks one of the first Canadian cases to factor in the relevant social context of race when interpreting the meaning of detention under s. 9 of the Charter. In Griffiths, the police approached a street corner in Toronto that they claimed to be an area known for drug trafficking. A group of Black men standing on the corner dispersed as the police approached. The police called out to the accused and said something to the effect of "hey you, come over here." The accused testified that given the history of police brutality towards young Black men in the city, he felt that he had no choice but to comply. Based on the accused's testimony and the evidence of systemic racism, the trial judge was satisfied that the accused had been detained by the police. In reaching this conclusion, Bovard J. likely asked himself: can it really be said that it is reasonable to expect that a young Black man in Toronto would feel free to refuse an officer's request to "come over" or to "stop"? ${ }^{131}$

See, for example, the review of cases in R.v. H.(C.R.) (2003), 173 Man. R. (2d) 113, 11 C.R. (6th) 152 (C.A.). This narrow approach mirrors the approach taken under s. 10 of the Charter. Unfortunately, in R. v. Hufsky, [1988] 1 S.C.R. 621 at 632, (1988) 63 C.R. (3d) 14, Le Dain J. held that "[a]lthough Therens and Thomsen were concerned with the meaning of 'detention' in s. 10 of the Charter, there is, in my opinion, no reason in principle why the general approach to the meaning of detention reflected in those cases should not be applied to the meaning of 'detained' in s.9." Hopefully, the argument presented above will serve as a good reason in principle, to use the words of Le Dain J., to develop a different approach to detention under s. 9 . In the United States, a similar argument has been made by Robert L. Bogomolny, "Street Patrol: The Decision to Stop a Citizen" (1976) 12 Crim. L. Bull. 544 at 560-67.

131 See the discussion of Griffiths in David M. Tanovich, "R. v. Griffiths: Race And Arbitrary Detention" (2003), 11 C.R. (6th) 149. In an unrelated context, see R. v. Pinto, [2003] O.J. No. 5172 at para. 46 (S.C.J.) (QL), where Hill J. adopted a social context approach in determining whether there was a valid consent to search under s. 8 of the Charter: "While this is acknowledged by all parties not to be a case about racial profiling, the experience and perspective of visible minorities respecting the police often serves to inform their beliefs about the realistic existence of free choice in dealing with the police." 


\section{ConClusion}

The use of race by the police as a basis to target individuals for a criminal investigation is not only a manifestation of systemic racism and an unreliable law enforcement tool, but it has had devastating and deadly consequences for the effected communities. Alienation, distrust, over-representation in the criminal justice system, stigmatization, and widespread harassment are only some of the collateral social problems that flow from this practice. The time has come to seriously address this issue in Toronto and to identify its existence in other parts of Canada. Those concerned with this issue are not, in the words of Chief Fantino, "making mischief at our expense" but, rather, attempting to remedy a social problem that causes considerable damage to our society. 